(Jpn. J. Hosp. Pharm.

投与間隔設定用ノモグラムを利用したバンコマイシンの

処方適正化と添付文書記載内容の検討

森田邦彦，小西廣己，山路 昭

滋賀医科大学医学部附属病院薬骩部门

\title{
Problems in the Descriptions in a Package Insert for Vancomycin Injection, and the Utility of the Nomogram Method to Determine Its Dosing Interval
}

\author{
KUNIHIKO MORITA, HIROKI KONISHI and AKIRA YAMAJI \\ Department of Hospital Pharmacy, Shiga University of Medical Science $†$
}

$\left(\begin{array}{llc}\text { Received August 20, } & 1996 \\ \text { Accepted Februay } 20, & 1997\end{array}\right)$

To elcidate the factors leading to hindrance for the rationalization of dosage regimen of vancomycin (VCM), its therapeutic drug monitoring (TDM) data obtained from 64 patients were reviewed, and the utility of a nomogram method to determine the daily dosage of VCM (Nomogram Dose $_{\text {) }}$ described in the package insert of VCM injection was examined in comparison with another nomogram method to determine the dosing interval (Nomogram ${ }_{\mathrm{Int}}$ ) which was reported by Matzke et al. Before starting the dosage regimen, the serum peak and trough levels of VCM in the almost patients deviated from their therapeutic ranges (peak, $25-40 \mu \mathrm{g} / \mathrm{ml}$; trough, $\leqq 10 \mu \mathrm{g} / \mathrm{ml}$ ), because the uniform dosage based on the descriptions in the package insert were performed for the patients with various degrees of renal functions. The after dosage regimen by using Nomogram $_{\text {Int }}$, the serum peak and trough levels of VCM in the subjects were controlled within their therapeutic ranges as a result of the uniform dosing interval of 8 or 12 hours in the early step of dosing were corrected to 18-56 hours according to the values of creatinine clearance (CLcr) in the patients. On the other hand, the serum level of VCM was poorly controlled within its therapeutic ranges after starting the dosage regimen by using a Nomogram Dose, $_{\text {, because the nomogram provided }}$ only the daily dose but not the optimum dosing interval. To aleat all physicians to the problem of the dosage regimen of VCM, a letter including these results was thus distributed to all wards in our hospital. Thereafter, the percentage of well controlled subjects, in the early dosage step increased to about 10-fold which was about as much as that before the information was disseminated.

Based on the present results we strongly recommend the package descriptions inside VCM package should thus be revised for adoption in clinical practice. 
Key words — vancomycin, therapeutic drug monitoring, nomogram, package insert, creatinine clearance

メチシリン耐性黄色ブドウ球菌（MRSA）感染 症に有効な塩酸バンコマイシン (VCM) の点滴 静注に際しては，腎機能障害患者での排泄遅延 や，腎毒性あるいは聴覚毒性の発現と血中濃度と の関連性など, いくつかの留意すべき点のあるこ とが知られている ${ }^{1-6)}$. 実際，これらの点を考虑 して投与量を設定すべきことについては，VCM の添付文書にも詳述されており，処方医の認識も 使用頻度とともに高まりつつあるといえよう。

一方, VCMの血中濃度モニタリング（TDM） にもとづいた研究報告のなかには, 添付文書に記 載されている腎機能低下患者への投与量設定用ノ モグラム (用量法 $)^{3)}$ の有用性を疑問視するもの 7 ) や, 添付文書に記載のない投与間隔の設定を推奖 するもの ${ }^{8)}$ が見られる。これらの報告を総合する と，添付文書の記述を指針とした現在の VCM の 処方内容が, 必ずしも適正とは言い切れない実態 を含んでいることが推察される。

筆者らは，VCMの処方を適正化する上で障害 となる要因を明らかにすべく, 現在提唱されてい る患者のクレアチニン・クリアランス (CLcr) 值にもとづく二つのノモグラム法, すなわち添付 文書記載の用量法（Fig. 2) と, 固定された投与 量（初回 $25 \mathrm{mg} / \mathrm{kg}, 2$ 回目以降 $19 \mathrm{mg} / \mathrm{kg}$ ) のもと にCLcr 值に応じた投与間隔を設定できる Matzke らの方法（投与間隔法, Fig. 2) ${ }^{4)}$ の有用性を比 較し, その結果にもとづいた院内の広報活動の前 後での処方内容および TDM データの変遷を調査 した。

\section{方法}

\section{1. 対象}

滋賀医科大学病院の入院患者のうち,1992年 7 月から1996年 6 月までの 4 年間に, VCM の TDM

$\dagger$ 大津市瀬田月輪町 ; Seta, Ohtsu, 520-21. Japan
が実施された64症例（男性46名，女性18名，平均

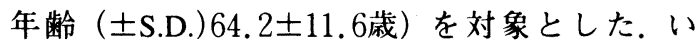
ずれの症例の場合も, VCM の投与開始後 $3 \sim 5$ 日目に提出された血清検体のピークとトラフの各 值の判定内容，投与スケジュール，および投与期 間を通してのCLcr 值を調査した。また上記 4 年 間の調査対象期間を，後述する「VCM 投与に際 しての留意点」(「留意点」) と題した文書を全病棟 に配布した1994年 7 月を境として，それ以前の 2 年間(前期, 24 症例) と配布後の 2 年間(後期，40症例) の 2 期に分け，各期間の TDM データおよび処方 内容を比較した。

\section{2. 各ノモグラムの有用性の比較}

VCMの血中濃度コントロールが不良と判断さ れた前期の症例のうち，12症例を対象とした。こ のうちの 6 症例には用量法を, 残りの 6 症例には 投与間隔法を，それぞれ用いて処方内容の変更を 主治医に助言し，それに添って処方変更が実施さ れた後 $3 \sim 8$ 日目の血清ピークおよびトラフ濃度 を評価した。この場合，いずれの患者群の CLcr 值も $20 \sim 60 \mathrm{ml} / \mathrm{min}$ 台にあり, 用量法 (平均值士 $\mathrm{SD} ： 42.7 \pm 9.2 \mathrm{ml} / \mathrm{min}$ ) と投与間隔法（同： 46.4 $\pm 13.5 \mathrm{ml} / \mathrm{min}$ ) の群間の腎機能に有意差のない 条件で実施した。

\section{3. 血清 VCM 濃度の測定と TDM データの評価}

血清 VCM 濃度の測定は, 蛍光偏光免疫測定法 にて行い, 点滴静注終了後 1 時間目と次回投与の 1 時間前〜直前の值を，それぞれピーク值および トラフ值として評価の対象とした。ピーク値は 25 $\sim 40 \mu \mathrm{g} / \mathrm{ml}$ を，またトラフ值は MIC 以上かつ 10 $\mu \mathrm{g} / \mathrm{ml}$ 以下を, それぞれ有効・安全域の指標と した、VCMの血中動態シミュレーションは, 塩 野義製薬株式会社で開発されたコンピュータープ ログラム・塩酸バンコマイシン TDM 血中濃度デ 一タ解析システム（VCM-TDM）を用い，2-コ ンパートメントモデルにもとづく Rodvold らの母 
集団パラメータ(')を組み込んだベイジアン法に より実施した。

\section{CLcr 值の算出}

各患者の臨床検査データのうち、VCM 投与開 始日からの血清クレアチニン值を経日的に抽出 し，Cockcroft \& Gault の換算式"淿にあてはめて CLcr 值を算出した.

\section{5. 統計処理}

各群間の比較は, Student’s t-testを用いた。

\section{結果および考察}

1. 各ノモグラム法の有用性の比較と, その結果 にもとつく院内広報活動

投与開始期の処方設定が不適切なため, VCM の血中濃度がピークあるいはトラフの各指標から 逸脱していた前期の症例のうち添付文書記載の用 量法あるいは Matzke らの投与間隔法の各ノモグ ラムにより主治医に処方変更を促した全12症例の 結果を Table 1 に示す. 投与間隔法を用いた場 合, Matzke らが提唱する用量設定（維持量 $19 \mathrm{mg}$ ) $\mathrm{kg} /$ 回）にしたがった 1 回の投与量は半数の症例 で増量，残り半数は不変であったが，いずれの場 合も投与間隔は1.5〜 4倍に延長され，その結果 全例でピークとトラフの双方の值が指標域に良好 にコントロールされた。一方，用量法を用いて 1 日の投与量を修正し，添付文書の記述にしたがっ て12時間ごとに分割した場合，ほとんどのケース で1 日の用量は下方修正されたものの，その後も トラフとピークの双方の值が指標域にコントロー ルされた例はなく，一部を除いてトラフ值は依然 として高值を保ったままで, 逆にピーク值は指標 域下限を下回ることになった。

Table 1 の症例のうち, 典型的な 4 例について のシミュレーション結果を Fig. 1 に示す. A(患者 No. 1 ) およびB (患者No. 7 ) は, いずれも CLcr 值が $20 \mathrm{ml} / \mathrm{min}$ 台の高度腎機能障害例であったに もかかわらず，初期の処方で VCM として $2 \mathrm{~g} /$ 日 を12時間ごとに分割投与された結果, 血中濃度は 指標域上限を大きく逸脱していた。投与間隔法を
あてはめた A の場合，1回の用量を維持量 $19 \mathrm{mg} /$ $\mathrm{kg}$ の条件に近似する $1 \mathrm{~g}$ とし， CLcr值をノモグ ラムにあてはめて得られた48時間間隔での投与に 変更した結果，その後はピーク值およびトラフ值 ともに指標域内にコントロールさせることができ た。一方，投与間隔の条件設定のない用量法をあ てはめた Bの場合は，CLcr 值に対応した用量で ある $0.5 \mathrm{~g} /$ 日をノモグラムから読み取り, 変更前 の処方同様に 12 時間ごとに分割したところ，ピー ク值は指標域に達せず，逆にトラフ值は指標上限 值を上回ることになった.CLcr 值が $50 〜 60 \mathrm{ml} /$ $\min$ 台の軽度腎機能障害例である C(患者 No. 2) およびD（患者No. 8 ）の場合は，変更前の処方 ではいずれも VCM として $0.5 \mathrm{~g} /$ 日を 12 時間ごと に分割投与され，1回の用量が低すぎてピーク值 が指標域に到達しなかった症例である．投与間隔 法をあてはめた C の場合，1回の用量を維持量 $19 \mathrm{mg} / \mathrm{kg}$ の条件に近似する $0.75 \mathrm{~g}$ とし, CLcr值 をノモグラムに当てはめて得られた18時間間隔で の投与に変更した結果, その後のピークおよびト ラフ值は，いずれも指標域内に良好にコントロー ルされた。一方,用量法をあてはめた Dの場合 は,ノモグラムから読み取られた $0.8 \mathrm{~g} /$ 日の用量を 初期処方同様に 12 時間ごとに分割した結果, ピー ク值はその後も依然として指標域に達しなかっ た。

VCM の血清中濃度をトラフおよびピークの双 方の至適領域に到達させることは，腎毒性などの 副作用の回避とともに，MRSA を早期に陰性化 させるために重要とされる．以上の検討の結果， VCM の投与設計には 1 回の用量と腎機能に応じ た投与間隔という二つの要素の適切な設定が必要 不可欠であり，添付文書に記載されている 1 日 2 $\mathrm{g}$ の分割投与法や用量設定用ノモグラムは，上記 の要素を満たすものではないと判断された.

これらの VCM 療法上の問題点への注意を喚起 するとともに，良好な成績を納めた投与間隔設定 用ノモグラム法を処方設計に活用すべく，1994年 7 月, Fig. 2 に示す広報文書・「留意点」を当院 
Table 1. 各ノモグラムによる投与スケジュール変更前後での VCM 血中濃度コントロー ルの良否判定

\begin{tabular}{|c|c|c|c|c|c|c|c|c|c|c|c|}
\hline & & & & & & & & & M 血中 & $\sum(\mu g / m 1)$ & ק \\
\hline & 者者No. & 性別 & 年的 & 体而 & & (m1/min) & 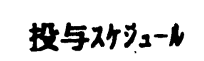 & 日数 & トラフ & ピーク & 判定") \\
\hline & 1 & $\mathbf{F}$ & 69 & 49 & 麦更前 & 24.0 & $1.0 \mathrm{~g} / 12 \mathrm{~h}$ & 4 & 42.0 & 58.1 & 不良 \\
\hline & & & & & " 䴰 & 26.0 & $1.0 \mathrm{~g} / 48 \mathrm{~h}$ & 8 & 9.8 & 27.9 & 良好 \\
\hline & 2 & $\mathbf{F}$ & 68 & 45 & 麦更前 & 62.0 & $0.25 \mathrm{~g} / 12 \mathrm{~h}$ & 5 & 5.6 & 12.4 & 不良 \\
\hline 投 & & & & & “绻 & 62.0 & $0.75 g / 18 h$ & 4 & 6.7 & 33.2 & 良好 \\
\hline 与 & 3 & $\mathbf{M}$ & 61 & 51 & 紊夏前 & 44.3 & $1.0 \mathrm{~g} / 24 \mathrm{~h}$ & 5 & 32.2 & 51.2 & 不良 \\
\hline & & & & & “徏 & 43.0 & $1.0 \mathrm{~g} / 48 \mathrm{~h}$ & 6 & 10.0 & 29.7 & 良好 \\
\hline 間 & 4 & $\mathbf{M}$ & 64 & 56 & 変更前 & 48.0 & $1.0 \mathrm{~g} / 12 \mathrm{~h}$ & 5 & 26.3 & 46.5 & 不良 \\
\hline ( & & & & & “锣 & 47.8 & $1.0 \mathrm{~g} / 24 \mathrm{~h}$ & 4 & 9.5 & 39.3 & 良好 \\
\hline & 5 & $\mathbf{M}$ & 48 & 46 & 麦更前 & 58.0 & $0.5 \mathrm{~g} / 8 \mathrm{~h}$ & 7 & 27.5 & 49.8 & 不良 \\
\hline 法 & & & & & "传 & 55.3 & $1.0 \mathrm{~g} / 24 \mathrm{~h}$ & 10 & 7.8 & 35.9 & 良好 \\
\hline & 6 & $\mathbf{M}$ & 51 & 75 & 变更前 & 42.1 & $1.0 \mathrm{~g} / 12 \mathrm{~h}$ & 3 & 17.0 & 45.0 & 不良 \\
\hline & & & & & "镂 & 43.5 & $1.25 \mathrm{~g} / 36 \mathrm{~h}$ & 7 & 5.6 & 32.1 & 良好 \\
\hline & 7 & $\mathbf{M}$ & 60 & 46 & 変更的 & 26.0 & $1.0 \mathrm{~g} / 12 \mathrm{~h}$ & 5 & 40.0 & 56.1 & 不良 \\
\hline & & & & & "後 & 28.0 & $0.25 \mathrm{~g} / 12 \mathrm{~b}$ & 3 & 16.5 & 21.7 & 不良 \\
\hline & 8 & $\mathbf{F}$ & 50 & 47 & 麦更前 & 52.3 & $0.258 / 12 \mathrm{~h}$ & 3 & 8.3 & 13.6 & 不良 \\
\hline 用 & & & & & “俊 & 52.3 & $0.4 \mathrm{~g} / 12 \mathrm{~h}$ & 3 & 10.0 & 18.9 & 不良 \\
\hline & 9 & $\mathbf{M}$ & 79 & 53 & 变更前 & 41.7 & $0.5 \mathrm{~g} / 12 \mathrm{~h}$ & 4 & 16.6 & 23.5 & 不良 \\
\hline & & & & & "镜 & 42.0 & $0.3 \mathrm{~g} / 12 \mathrm{~h}$ & 3 & 15.6 & 19.9 & 不良 \\
\hline & 10 & $\mathbf{F}$ & 75 & 38 & 変更前 & 42.0 & $0.5 \mathrm{~g} / 12 \mathrm{~h}$ & 4 & 14.6 & 21.1 & 不良 \\
\hline & & & & & 㖓 & 42.0 & $0.35 \mathrm{~g} / 12 \mathrm{~h}$ & 3 & 10.4 & 16.5 & 不良 \\
\hline 法 & 11 & $\mathbf{M}$ & 76 & 30 & 交更前 & 50.0 & $0.5 \mathrm{~g} / 12 \mathrm{~h}$ & 10 & 20.6 & 43.1 & 不良 \\
\hline & & & & & “掼 & 50.2 & $0.35 \mathrm{~g} / 12 \mathrm{~h}$ & 3 & 15.0 & 27.3 & 不良 \\
\hline & 12 & $\mathbf{M}$ & 62 & 50 & 変車胉 & 44.0 & $1.0 \mathrm{~g} / 24 \mathrm{~h}$ & 4 & 28.9 & 50.1 & 不良 \\
\hline & & & & & “徣 & 40.7 & $0.4 \mathrm{~g} / 12 \mathrm{~h}$ & 5 & 26.5 & 36.7 & 不良 \\
\hline
\end{tabular}

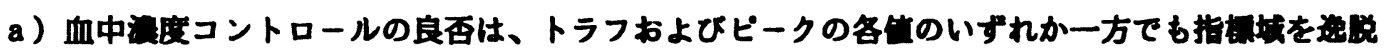
していれば不良、双方がともに各指柘域内にあれば良好とそれぞれ判定した。 
A. (患者No. 1)

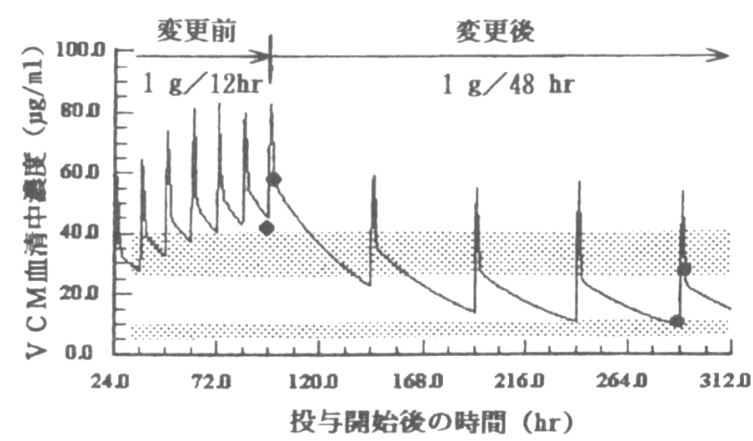

C. (患者No. 2)

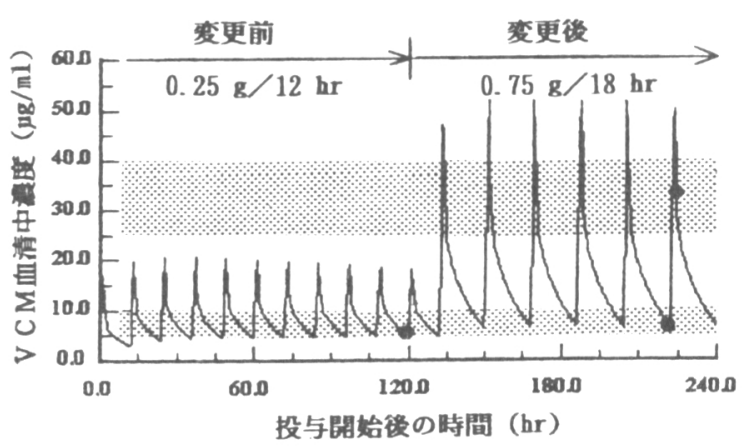

B. (患者No. 7)

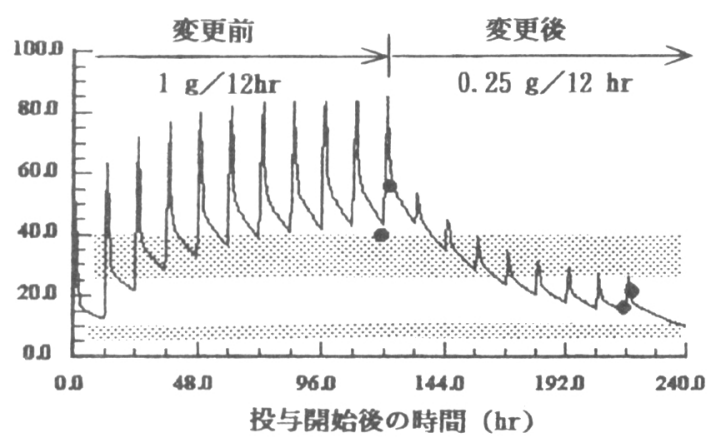

D. (患者No. 8)

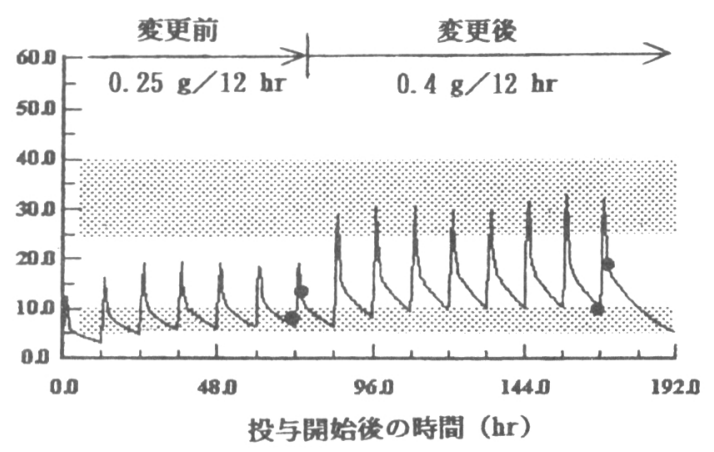

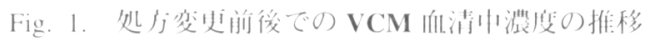

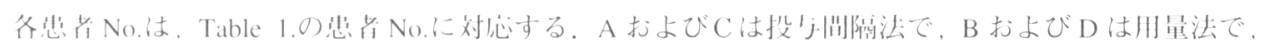

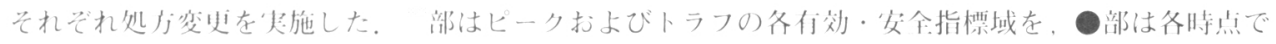
の长澌㑬をそそれぞれ小标。

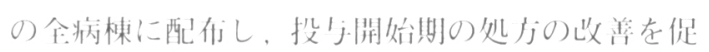
した。

2.「留意点」配布前後での処方内容と TDM デー 夕の変遷

CLer 值にもとづいて患考婜機能别に3段階

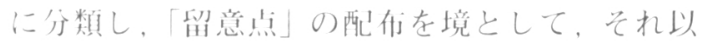

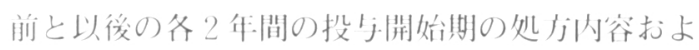
びTDMデータを比較した絬果在 Table 2 に小

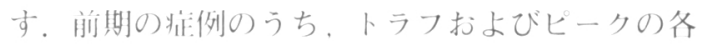
㑬が指呩域に適山にコントロールされ。退好と判

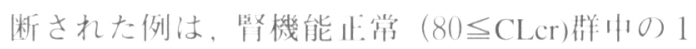
例のみで、軽中等度 $(40 \leqq \mathrm{CLCr}<80)$ 打よび高

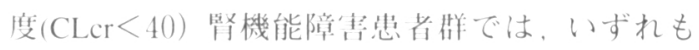

全例が不良であった。不良例のうち，婜機能正常 群で法ピークが著しく低俻であること、軽中等度 障售臂ではトラフが莦しく宫值であること, 宫度 障害荫ではトラフ打よびピークの双方ともに高优 であることが，それぞれ血中濃度の面から特徽づ けられた。

方，後期になると，条群とも良好例は $30 \%$ 台 を古めるまでに増㞦した。これら良好例の処方内 容は，前後期存問わず不良と判断された怔例のそ れとは明らかに型なっていた。すなわち 1 回の投 与量法良好例（平均17 - 20mg/ kg) が不良例（平 均10〜14mg/kg）より約1.5倍高く，投間隔は 艮好例の場今, 患者の婜機能の程度に忍じて平均 


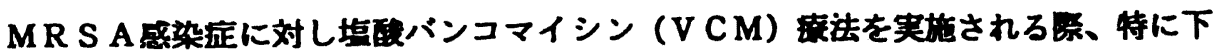
記の点にこ留意下さい。

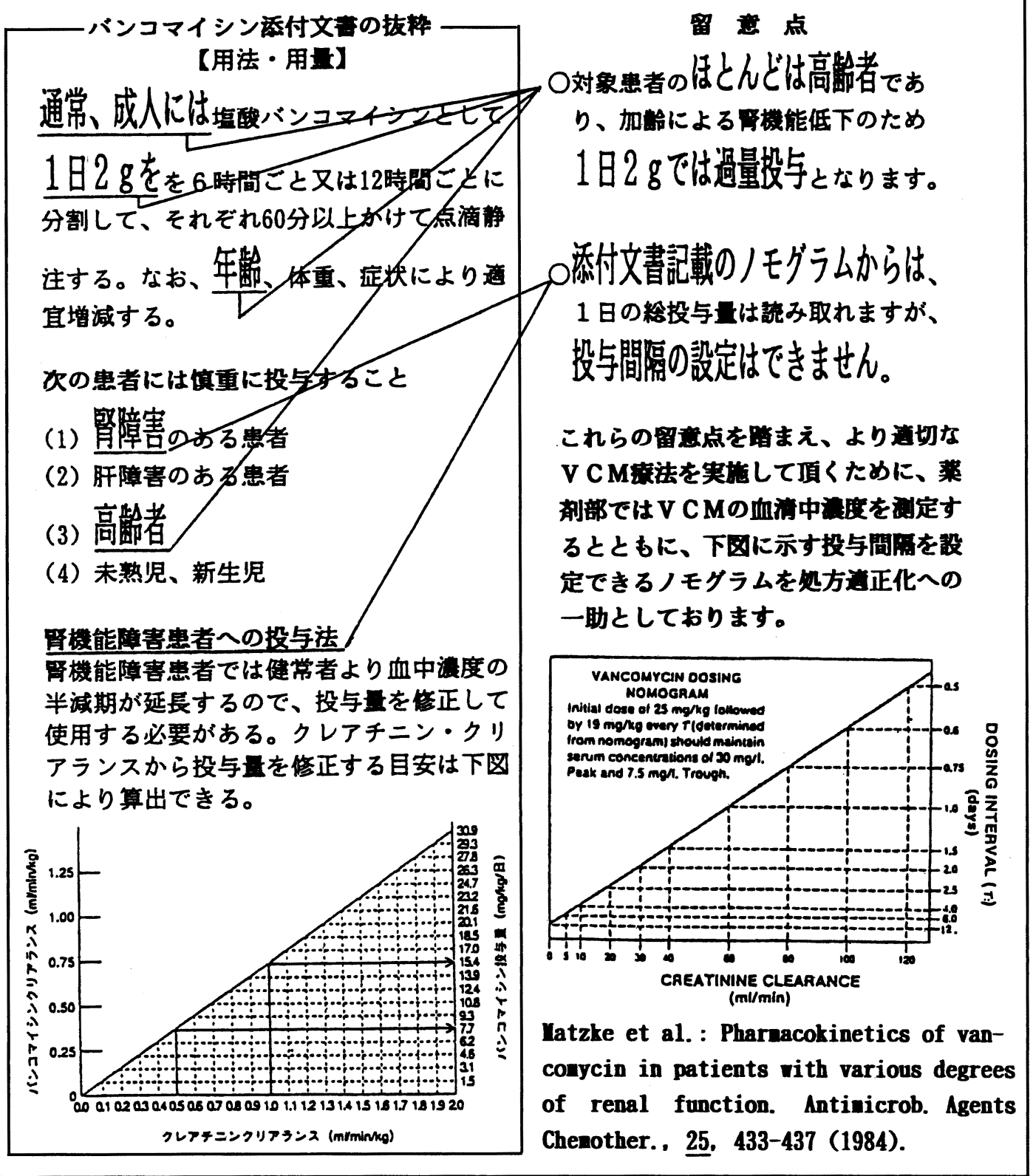

Fig. 2. 全病棟に配布した広報文書「VCM 投与に際しての留意点」

18時間から60時間まで延長され，腎機能の良否に よらず画一的（平均10～14）に設定された不良例 に比べ，有意に長い間隔に設定されていた。この
ことは,「留意点」配布により, Matzke らの提唱 する用量（初回量 $25 \mathrm{mg} / \mathrm{kg}$, 維持量 $19 \mathrm{mg} / \mathrm{kg}$ ) と 投与間隔設定用ノモグラムが投与初期の段階から 


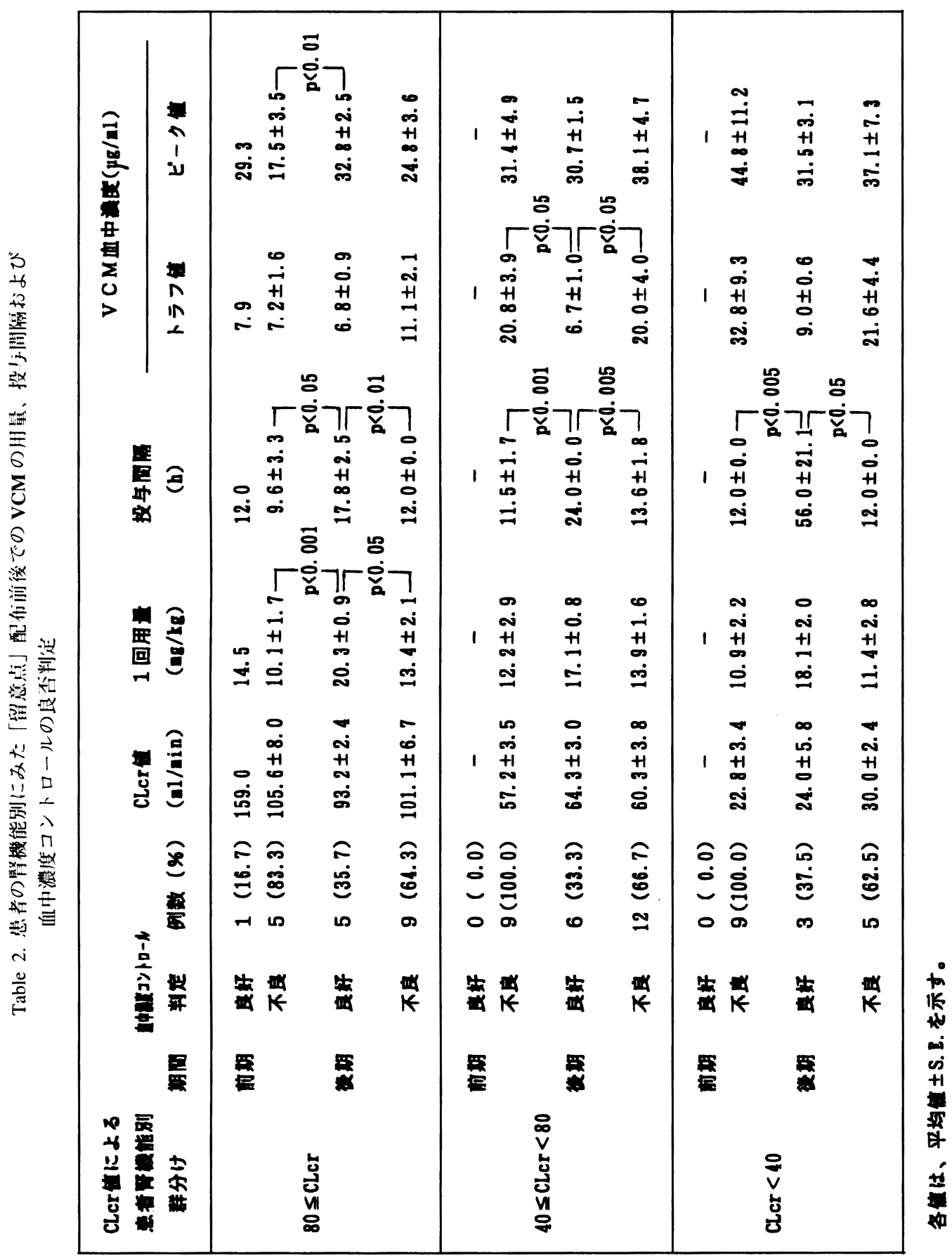

処方医に活用され始めた結果と考えられた。しか し後期に入っても60\%以上を占めた不良例は，そ れらの 1 回用量（11 14mg/kg）および投与間隔
（12 14時間）とも前期の処方内容と大差ないこ とから, 配布した「留意点」の処方医への浸透は 十分とはいえず，依然として「通常，成人には 
$\mathrm{VCM}$ として 1 日 $2 \mathrm{~g}$ を 6 時間ごと，または 12 時 間ごとに分割して〜」との添付文書の画一的な用 法・用量の項の表現 ${ }^{10)}$ が, 初期処方の指針とさ れる傾向の強いことが示唆された。

調查した症例の平均年齢が示すように, MRSA 患者のほとんどは高龄者であることから, VCM 投与は多くの場合，腎機能低下症例を対象として 実施されることになる．刻々と変動する患者の腎 機能に応じた投与を実施するためには，VCM 投 与後のきかめ細かな TDMの支援が必要であるこ とはいうまでもないが，初回投与の段階での処方 内容は，少なくともその時点での患者腎機能に対 応した最適なものとなるような指針が与えられる べきであり，特に高齢者の CLcr 值を簡便かつ高 精度で予測できるか否かが処方適正化を左右する 第一義的な要素といえよう。今回，我々が用いた Cockcroft \& Gault の式 ${ }^{9)}$ は現在最も沉用されて いる CLcr 予測式であるが，高龄者の腎機能の予 測には近年提唱されている血清アルブミン值を組 み込んだ CLCr 予測式 ${ }^{11)}$ が適するとの報告があ る。しかし，後者の式が MRSAによる炎症反応 にともなう血清アルブミン濃度の急激な変動 時12)にも有用か否かも含め, 今後の検討課題と 考えられる。

以上より，筆者らは現在の VCM の添付文書に 記載されている用量設定用ノモグラムを Matzke

\section{【用法・用量】}

通常、VCM として初回量 $25 \mathrm{mg} / \mathrm{kg}, 2$ 回目以降 $19 \mathrm{mg} / \mathrm{kg}$ を 患者の腎機能に応じた投与間隔をあけて点滴静注する。 投与間隔は、患者のクレアチニンクリアランス (CLCr) 値 にもとづく下記のノモグラムから読み取る。なお，CLcr 値 は、血清クレアチニン值から Cockcloft \& Gault の式※に より算出できる。

※予測 CLcr 值 $(\mathrm{ml} / \mathrm{min}) ：(140$ - 年路) $) \times$ 体重 $\mathrm{kg}$ $72 \times$ 血清クレアチニン値 $\mathrm{mg} / \mathrm{dl}$

女性患者に場合は、上記値を 0.85 倍する。

Fig. 3. VCM 添付文書の「用法·用量」の記 述内容改訂案
らの投与間隔設定用ノモグラムに変更すること， ならびに添付文書の「用法・用量」の記述内容 を，例えば Fig. 3 に示す一案のように改訂する ことを提唱するものである。

謝辞 本研究の遂行に際し，Matzkeらのノモグラ ムに関する有益な情報を提供いただいた山形大学医学 部附属病院薬片部 豊口禎子先生に厚く御礼申し上げ ます。

\section{引用文献}

1) J. E. Geraci, F. R. Heilman, D. R. Nichols and W. E. Wellman, Proc. Mayo. Clin., 33, 172-181 (1985).

2) W. Leach, J. Laryngol. Otol., 76, 774-790 (1962).

3) R. C Moellering Jr., D. J. Krogstad and D. J. Greenblatt, Ann. Intern. Med., 94, 343346 (1981).

4) G. R. Matzke, R. W. McGory, C. E. Halstenson and W. F. Keane, Antimicrob. Agents Chemother., 25, 433-437 (1984).

5) G.B.Appel, D. B. Given, L.R. Levine and G.L. Cooper, Am. J. Kidney Dis., 8, 75-80 (1986).

6) K. A. Rodvold, R. A. Blum, J. H. Fischer, H. Z. Zokufa, J. C. Rotschafer, K. B. Crossley and L. J. Riff, Antimicrob. Agents Chemother., 32, 848-852 (1986).

7) 江藤和裕, 松山賢治, 市川正孝, 賀来満夫, TDM 研究, 12, 47-52 (1995).

8）山崎顕，篠崎公一，高尾良洋，田中美雄，高橋 悟, 長山義明, 斎藤宣彦, 田中克之, 田口芳雄, 関野宏明，高橋悦子，三木勝代，杉山和夫，市 川陽一, TDM 研究, 13, 174-181 (1996).

9) D. W. Cockcloft and M. H. Gault, Nephron, 16, 31-41 (1976).

10）塩酸バンコマイシン点滴静注用添付文書，塩野 義製薬株式会社, 1995 年.

11) 佐仲雅樹, 高野喜久雄, 島倉和朗, 峰下哲, 臨 床薬理, 25, 91-92 (1994).

12) K. Morita, H. Konishi and A. Yamaji, Ther. Drug Monit., 投稿中. 